\title{
Macronutrients and water - do they matter in the context of cognitive performance in athletes?
}

\author{
Authors' Contribution: \\ A Study Design \\ B Data Collection \\ C Statistical Analysis \\ D Data Interpretation \\ E Manuscript Preparation \\ F Literature Search \\ G Funds Collection \\ Ewa Karpęcka1 BDEF, Barbara Frączek ${ }^{2}$ ADEF \\ ${ }^{1}$ University School of Physical Education in Krakow, Poland \\ 2 Department of Sports Medicine and Human Nutrition, Faculty of Physical Education \\ and Sport, University School of Physical Education in Krakow, Poland
}

Proper nutrition is a key factor in physical performance, but there are also indications of an impact of dietary components on the brain function. Therefore, the aim of the study was to assess the impact of macronutrients and water on cognitive performance. Assumptions of the Mediterranean diet correlate with better global cognition, episodic memory, lower risk of cognitive impairment and neurodegenerative diseases. In turn, a high-fat and high-sugar diet shows the opposite effect. Omega-3 fatty acids could be used as a preventive tool for cognitive decline, but there is still insufficient evidence if supplementation improves cognitive functions. The proper intake of protein may be important in cognitive performance. Tyrosine seems to be potentially effective in inhibition of fatigue under extreme conditions, and the influence of BCAA on cognitive performance is still unclear. An appropriate glucose level is a critical factor for brain functions. Carbohydrate supplementation before and during exercise is associated with enhanced brain activation and decreased exercise perception, as well as improved cognitive functions. Dehydration worsens cognitive performance, especially for tasks requiring attention, executive functions and coordination. Based on the review of available studies, it should be assumed that proper nutrition might play a relevant role in athletes' cognitive performance.

Key words: cognitive performance, nutrition, macronutrients, water, athletes, exercise.

\section{article details}

Article statistics:

Full-text PDF:

Word count: 5,532; Tables: 5; Figures: 0; References: 140

Received: July 2019; Accepted: August 2020; Published: September 2020

Copyright

Indexation:

(n)

() Gdansk University of Physical Education and Sport, Poland

Celdes, Clarivate Analytics Emerging Sources Citation Index (ESCI), CNKI Scholar (China National Knowledge Infrastructure), CNPIEC, De Gruyter - IBR (International Bibliography of Reviews of Scholarly Literature in the Humanities and Social Sciences), De Gruyter - IBZ (International Bibliography of Periodical Literature in the Humanities and Social Sciences), DOAJ, EBSCO - Central \& Eastern European Academic Source, EBSCO - SPORTDiscus, EBSCO Discovery Service, Google Scholar, Index Copernicus, J-Gate, Naviga (Softweco, Primo Central (ExLibris), ProQuest - Family Health, ProQuest - Health \& Medical Complete, ProQuest - Illustrata: Health Sciences, ProQuest - Nursing \& Allied Health Source, Summon (Serials Solutions/ProQuest, TDOne (TDNet), Ulrich's Periodicals Directory/ulrichsweb, WorldCat (OCLC)

Funding: This research received no specific grant from any funding agency in the public, commercial, or not-for-profit sectors.

Conflict of interests: Corresponding author:

Open Access License: Authors have declared that no competing interest exists.

Ewa Karpęcka, Department of Sports Medicine and Human Nutrition, University School of Physical Education in Cracow, Al. Jana Pawła II 78, 31-571 Cracow, Poland; e-mail: karpeckaewa@gmail.com

This is an open access article distributed under the terms of the Creative Commons Attribution-Non-Commercial-NoDerivatives 4.0 International (https://creativecommons.org/licenses/by-nc-nd/4.0/), which permits use, distribution, and reproduction in any medium, provided the original work is properly cited, the use is non-commercial and is otherwise in compliance with the license. 


\section{INTRODUCTION}

Cognitive function is a key factor in athletic performance, and there is growing evidence that brain functioning can be influenced by some dietary components, an appropriate hydration level and supplements [1]. Nutrition provides four main classes of functional compounds for the brain to create and maintain connections, which is critical for improving cognition. Food delivers energy for the brain (essentially glucose), building blocks (e.g., lipids and amino acids), and micronutrients for enzymatic and endocrine processes (e.g., iron, zinc, B vitamins, iodine) and is a source of bio- or psychoactive molecules that can exert a multitude of brain-relevant actions [2, 3]. In addition, the organoleptic properties of food - such as taste, smell, and texture - may directly modulate cognition and mood [3, 4].

The aim of this study is to assess the impact of macronutrients and water on cognitive functions among active people. Other dietary components and supplements that affect the concentration and brain functions will be mentioned as well, but they are not the topic of this review.

\section{MATERIAL AND METHODS}

A systematic search was carried out by using following databases: Pubmed and Medline, SPORTDiscus, Academic Search Ultimate, Scopus, ScienceDirect for studies published in English from January 2010 till July 2020. Search terms included key words related to cognition, cognitive function, cognitive performance, brain, nutrition, omega-3 fatty acids, carbohydrates, protein, hydration, dehydration and sport. The systematic search resulted in 175 articles, which mostly were randomised, double-blind, placebo-controlled trials, review articles, systematic reviews, clinical case studies, comparative studies, clinical trials and meta-analysis.

\section{RESULTS AND DISCUSSION}

\section{DIET AND NUTRITIONAL HABITS}

For many years, diet, combined with other aspects of daily living, such as exercise, has had a crucial role in shaping cognitive capacity and brain evolution. According to palaeontologists, there is a direct relationship between access to food and the brain size, and that even small differences in diet can have large effects on survival and reproductive success [2]. Poor diet in utero and during early postnatal life can cause permanent changes in many aspects of metabolic and central functions, including impairments in cognition and accelerated brain aging [5]. Maternal gestational diabetes and even an inappropriate and junk food diet in the non-diabetic can lead to metabolic complications, including diabetes and obesity in the offspring $[6,7]$. It can also result in changes in reward processing in the offspring's brain so that they grow to prefer foods high in fat and sucrose $[8,9]$. On the other hand, some dietary supplements can positively influence cognition, as is seen with supplementation of baby formula with long chain omega-3 PUFA improving cognition in babies [10] (Table 2). Microglia are one of the major immune cell populations in the brain. In development, they are essential for synaptic pruning, while in a mature organism their major role is in mounting a proinflammatory immune response and phagocytosing pathogens and injured brain cells. Neuroinflammatory processes, including the role of microglia, can clearly be impacted by neonatal diet and represent at least one 
contributing mechanism of how cognitive function is affected [11]. The brain has a very high demand for nutrients in this early period and nutritional imbalances affect normal neurodevelopment resulting in lasting cognitive deficits [12]. Understanding the role of metabolic factors and specific nutrients in this context is crucial to develop effective peripheral (e.g., nutritional) intervention strategies [11].

The Western diet, which is rich in saturated fatty acids, sugar, and protein, is associated with an increased risk of developing obesity, type 2 diabetes, dementia, and it impairs object recognition learning in rats $[13,14]$. Furthermore, it creates a physiological profile in animal models akin to metabolic syndrome in humans, including greater visceral adiposity, dyslipidemia, hyperinsulinemia, and glucose intolerance. These diets have been linked to elevations in hippocampal inflammation, behavioural responses reflecting impulsivity and inability to maintain attention, but they may be reversible [15] (Table 1). Short-term postweaning exposure to a high-fat diet induces both cognitive impairment and transient anxiety-like behaviour in young mice, and a diet high in saturated fat is suggested to contribute to the development of depression-like behaviour in mice $[16,17]$. In addition, a Western diet is associated with increased depressive symptoms both over time and cross-sectionally in humans [18]. It has been proposed that these memory deficits are caused by increased inflammatory and decreased neuroplasticity markers $[19,20]$. The hippocampus is especially susceptible to the effects of this diet, as memory deficits are already evident after one week of dietary treatment [20,21]. High-fat diet consumption has been demonstrated to impair hippocampus-dependent memory function in humans and rodents. Many studies have shown that high-fat diet-induced cognitive deteriorations are accompanied by elevated neuroinflammatory markers or responses in the hippocampus [15,20-26]. There is growing evidence that highfat diets may compromise the hippocampus by sensitizing the immune cells (most likely microglia) of this brain structure, thus priming the inflammatory response to subsequent challenging stimuli $[24,25,27]$. Sobesky et al. demonstrated that high-fat diet consumption primes the cells of the hippocampus by elevating the glucocorticoid steroid hormone corticosterone in this region [25]. Despite its classic role as an immunosuppressant, there is increasing evidence demonstrating that corticosterone can prime hippocampal microglia and potentiate the inflammatory response to a subsequent challenge [28-30]. Noble and Kanoski summarised evidence predominantly from rodent studies and concluded that neurocognitive function (especially hippocampal dependent learning and memory) may be particularly vulnerable to high carbohydratehigh fat consumption during the perinatal and adolescence periods [31] (Table 1 ). Findings were mixed as to whether the negative impact of maternal diet on offspring cognitive function could be reversed or improved if offspring are weaned on a healthy diet. The impact of a high-sugar-high-fat diet was found to affect the memory function above and beyond absolute calorie intake, weight gain, or metabolic dysfunction, suggesting that refined fat- and carbohydraterich dietary composition is an independent driver of negative memory effects. The above conclusions were extended by Morris et al. by highlighting negative early life stress as a potential moderator of the poor diet-impaired memory relationship [32]. Their review suggests that, in addition to its own direct impact on cognitive function, early life stress may influence diet choices into adulthood by promoting poorer coping skills, stress-related or emotional eating, and greater consumption of high carbohydrate-high fat foods. The final reviews by Reichelt et al. focus on adolescence as the most important period when the impact of high-sugar-high-fat diets may be particularly impactful on neuroplasticity and reward-processing neurocircuitry, leading to enduring cognitive deficits $[33,34]$. 
On the other hand, Ding et al. conducted a study to explore the relationships between macronutrient intake and cognitive function. They concluded that the dietary pattern with high percentage of energy intake from fat and protein, and low-energy intake from carbohydrate might have been associated with cognitive decline in a Chinese population under 65 years of age [35] (Table 1). The effect of protein on cognitive function has received limited attention. Jakobsen et al. summarised that healthy young males fed a high protein diet improved reaction time [36] (Table 1). Furthermore, Du et al. examined the influence of the protein level and source on Barnes maze performance, satiety and plasma amino acid levels in male rats. Results demonstrate the importance of protein source for cognition and satiety enhancing effects of a high-protein meal [37] (Table 1).

Table 1. Impact of diet on the cognitive function

\begin{tabular}{|c|c|c|c|}
\hline $\begin{array}{l}\text { Subjects/methods/ } \\
\text { type of publication }\end{array}$ & Results & Conclusion & References \\
\hline 32 animal models (rats) & $\begin{array}{l}\text { High fat high sugar diet has } \\
\text { been linked to elevations in } \\
\text { hippocampal inflammation, } \\
\text { behavioural responses reflecting } \\
\text { impulsivity and inability to } \\
\text { sustain attention, and may be } \\
\text { reversible. }\end{array}$ & $\begin{array}{l}\text { High fat high sugar diet is } \\
\text { rather not recommended for } \\
\text { ability to sustain attention. }\end{array}$ & Tran et al., 2017 \\
\hline Review, rodent models & $\begin{array}{l}\text { Neurocognitive function } \\
\text { (especially hippocampal } \\
\text { dependent learning } \\
\text { and memory) may be } \\
\text { particularly vulnerable to } \\
\text { high carbohydrate-high fat } \\
\text { consumption during the } \\
\text { perinatal and adolescence } \\
\text { periods. Findings were mixed } \\
\text { as to whether the negative } \\
\text { impact of maternal diet on } \\
\text { offspring cognitive function } \\
\text { could be reversed or improved } \\
\text { if offspring are weaned on a } \\
\text { healthy diet. }\end{array}$ & $\begin{array}{l}\text { A high sugar-high fat } \\
\text { diet was found to impact } \\
\text { memory function above } \\
\text { and beyond absolute } \\
\text { calorie intake, weight gain, } \\
\text { or metabolic dysfunction, } \\
\text { suggesting that refined } \\
\text { fat- and carbohydrate-rich } \\
\text { dietary composition is } \\
\text { an independent driver of } \\
\text { negative memory effects. }\end{array}$ & $\begin{array}{l}\text { Noble and } \\
\text { Kanoski, } 2016\end{array}$ \\
\hline $\begin{array}{l}23 \text { healthy males (age: } \\
19-31 \text { years), randomised, } \\
\text { single blinded, parallel } \\
\text { intervention study }\end{array}$ & $\begin{array}{l}\text { The high protein group } \\
\text { improved their reaction time } \\
\text { significantly compared with the } \\
\text { usual group. Branched chain } \\
\text { amino acids and phenylalanine } \\
\text { in plasma were significantly } \\
\text { increased following the HP diet, } \\
\text { which may explain the improved } \\
\text { reaction time. }\end{array}$ & $\begin{array}{l}\text { Healthy young males fed } \\
\text { a HP diet improved their } \\
\text { reaction time. }\end{array}$ & $\begin{array}{l}\text { Jakobsen et al., } \\
2011\end{array}$ \\
\hline Male Sprague-Dawley rats & $\begin{array}{l}\text { Both Egg White (EW) and } \\
\text { Wheat Gluten (WG) increased } \\
\text { postprandial concentrations } \\
\text { of large neutral and branched } \\
\text { chain amino acids relative to } \\
\text { Basal, but in EW, concentrations } \\
\text { were slower to peak, and } \\
\text { peaked to a higher level than } \\
\text { WG. }\end{array}$ & $\begin{array}{l}\text { Results demonstrate the } \\
\text { importance of protein source } \\
\text { for cognition and satiety } \\
\text { enhancing effects of a high- } \\
\text { protein meal. }\end{array}$ & Du et al., 2018 \\
\hline $\begin{array}{l}661 \text { participants; } 80 \text { with } \\
\text { mild cognitive impairment } \\
\text { (MCl) and } 581 \text { with normal } \\
\text { cognitive functions. }\end{array}$ & $\begin{array}{l}\text { The results revealed that high } \\
\text { percentage and high \% protein } \\
\text { intake were greatly associated } \\
\text { with an increased frequency of } \\
\mathrm{MCl} \text {, while high \% carbohydrate } \\
\text { intake was correlated with } \\
\text { decreased prevalence of } \mathrm{MCl} \text {. }\end{array}$ & $\begin{array}{l}\text { The dietary pattern with } \\
\text { high percentage of energy } \\
\text { intake from fat and protein, } \\
\text { and low-energy intake } \\
\text { from carbohydrate might } \\
\text { have been associated } \\
\text { with cognitive decline in a } \\
\text { Chinese population under } 65 \\
\text { years of age. }\end{array}$ & Ding et al., 2018 \\
\hline $\begin{array}{l}120 \text { children and } \\
\text { adolescents ( } 60 \text { with } \\
\text { newly diagnosed ADHD } \\
\text { and } 60 \text { controls) }\end{array}$ & $\begin{array}{l}\text { Lower adherence to a } \\
\text { Mediterranean diet was } \\
\text { associated with ADHD } \\
\text { diagnosis. }\end{array}$ & $\begin{array}{l}\text { Low adherence to a } \\
\text { Mediterranean diet might } \\
\text { play a role in ADHD } \\
\text { development. }\end{array}$ & $\begin{array}{l}\text { Ríos-Hernández } \\
\text { et al., } 2017\end{array}$ \\
\hline
\end{tabular}


Meta-analyses indicate that higher adherence to the Mediterranean diet is associated with better global cognition, episodic memory, lower risk of cognitive impairment and neurodegenerative diseases [38-40]. Ríos-Hernández et al., testing the impact of the Mediterranean diet (typically low in refined sugars) among 120 children and adolescents, found that lower adherence to the Mediterranean diet yielded a higher risk of attention-deficit/hyperactivity diagnosis [41] (Table 1). Adherence to the Mediterranean diet, as well as the Dietary Approaches to Stop Hypertension (DASH) diet and the Mediterranean DASH Intervention for Neurodegenerative Delay (MIND) diet is associated with less cognitive decline and a lower risk of Alzheimer's disease. Evidence that these diets are associated with dementia risk is inconsistent. The consumption of olive oil seems to be an important element underlying the neuroprotective effects of these diets [40].

Breakfast eating is the healthy nutritional habit, influencing athletes' cognitive performance, associated with increased intake of key nutrients. Poorer performance may result from a lack of available energy and, consequently, lower blood glucose. One experimental strategy that takes advantage of this naturally occurring event is to examine the effect of breakfast consumption on mental performance. On waking, people have effectively fasted for 6 to $8 \mathrm{~h}$, and cognitive loads that demand extra energy are likely to be identified [42]. Research exploring early morning food consumption suggests that the absence of breakfast can lead to a reduction in reaction time and short-term memory [43]. This psychological effect is most profound in studies of more mature adults [44]. A number of studies reported that cognitive function, such as working memory and executive function, was better following breakfast consumption as compared with that following breakfast omission [42,45-47]. Furthermore, for cognitive function, low glycaemic index (GI) breakfast seems to be better than high GI meal possibly due to stable glucose supply to nerve cell and/or favourable modulation of neurotransmitters and hormones [48-50]. In addition, studies focusing on school populations suggest that breakfast omission may detrimentally affect children's cognitive performance [51]. These findings shed light onto potential cognitive impairment in athletes who do not follow an appropriate nutrition protocol. Maintenance of an adequate blood glucose concentration is required to maintain optimal cognitive function, and enhancing glucose availability appears to improve cognitive performance $[42,52]$. Komiyama et al. examined the cognitive function at rest and during exercise following breakfast omission. The results show that skipping breakfast impairs executive function, but harsh exercise improves executive function even when skipping breakfast. The authors suggest the benefits of harsh exercise on cognition appear to be unaffected by skipping breakfast [53] (Table 4). Research is also being conducted to assess effects of breakfast omission on performance in resistance-type exercise. This study found that skipping breakfast before the test may impair resistance exercise performance in those who habitually ate breakfast [54] (Table 4).

\section{MACRONUTRIENTS}

\subsection{LIPIDS}

Lipids are approximately $10 \%$ of the brain weight and $50 \%$ of the dry weight [55]. Dietary lipids have been implicated in brain functioning at all stages of life. The role of dietary omega-3 and 6 family fatty acids has received much interest in a neurodevelopmental context, cognitive aging as well as in specific conditions and neuropsychiatric diseases, such as attention-deficit hyperactivity disorder, depression, bipolar disorder schizophrenia and dementia [56-64]. 
Table 2. Impact of fat on the cognitive function

\begin{tabular}{|c|c|c|c|}
\hline $\begin{array}{l}\text { Subjects and } \\
\text { methods }\end{array}$ & Results & Conclusion & References \\
\hline $\begin{array}{l}229 \text { infants from } \\
3, \text { randomised } \\
\text { controlled trials }\end{array}$ & $\begin{array}{l}\text { In the } 12 \text {-month feeding and } 6 \text {-week } \\
\text { weaning studies, supplemented children } \\
\text { had more intentional solutions (successful } \\
\text { task completions) and higher intention } \\
\text { scores (goal-directed behaviours) than } \\
\text { controls. }\end{array}$ & $\begin{array}{l}\text { Long-chain } \\
\text { polyunsaturated fatty } \\
\text { acids supplementation } \\
\text { improves means-end } \\
\text { problem solving. }\end{array}$ & $\begin{array}{l}\text { Drover et al., } \\
2009\end{array}$ \\
\hline Review & $\begin{array}{l}\text { Abnormal omega-3 PUFA levels have been } \\
\text { extensively described in both the peripheral } \\
\text { tissues and in the brain of patients with } \\
\text { mood disorders or cognitive decline. }\end{array}$ & $\begin{array}{l}\text { Diet and drugs targeting } \\
\text { PUFAs may lead to novel } \\
\text { therapeutic approaches } \\
\text { for the prevention and } \\
\text { treatment of brain } \\
\text { disorders. }\end{array}$ & $\begin{array}{l}\text { Bazinet et al., } \\
2014\end{array}$ \\
\hline Review & $\begin{array}{l}\text { Human studies suggest low n-3 red blood } \\
\text { cell PUFA concentrations and correlations } \\
\text { with clinical severity in studies of plasma } \\
\text { concentrations in symptomatic bipolar } \\
\text { disorder. Results of published n-3 PUFA } \\
\text { dietary supplementation trials for bipolar } \\
\text { disorder indicate efficacy in treatment for } \\
\text { mania or depression in } 5 \text { of } 5 \text { open-label } \\
\text { trials, efficacy in treatment of depression } \\
\text { in } 1 \text { of } 7 \text { randomised controlled trials, and } \\
\text { a signal for treatment of depression in } 1 \\
\text { meta-analysis. }\end{array}$ & $\begin{array}{l}\text { Biomarker studies of PUFA } \\
\text { and treatment studies } \\
\text { of } n-3 \text { PUFA in bipolar } \\
\text { disorder show promise for } \\
\text { indicating a way forward } \\
\text { in the study of PUFA in } \\
\text { bipolar disorder. }\end{array}$ & $\begin{array}{l}\text { Saunders et } \\
\text { al., } 2016\end{array}$ \\
\hline Review & $\begin{array}{l}\text { The main evidence for the effectiveness } \\
\text { of eicosapentaenoic acid (EPA) and } \\
\text { docosahexaenoic acid (DHA) has been } \\
\text { obtained in mood disorders, in particular } \\
\text { in the treatment of depressive symptoms } \\
\text { in unipolar and bipolar depression. There } \\
\text { is some evidence to support the use of } \\
\text { omega-3 fatty acids in the treatment of } \\
\text { conditions characterised by a high level of } \\
\text { impulsivity and aggression and borderline } \\
\text { personality disorders. The most promising } \\
\text { results have been reported by studies using } \\
\text { high doses of EPA or the association of } \\
\text { omega-3 and omega- } 6 \text { fatty acids. }\end{array}$ & $\begin{array}{l}\text { Supplementation or } \\
\text { appropriate intake } \\
\text { with diet recommend. } \\
\text { Omega-3 can be } \\
\text { considered safe and well } \\
\text { tolerated at doses up to } \\
5 \text { g/day. }\end{array}$ & $\begin{array}{l}\text { Bozzatello et } \\
\text { al., } 2016\end{array}$ \\
\hline $\begin{array}{l}155 \text { subjects with } \\
\text { Major Depressive } \\
\text { Disorder }\end{array}$ & $\begin{array}{l}\text { Subjects with specific combinations of } \\
\text { inflammatory markers were more likely to } \\
\text { respond to EPA treatment and less likely to } \\
\text { respond to placebo treatment. }\end{array}$ & $\begin{array}{l}\text { Obese subjects with MDD } \\
\text { are more likely to have } \\
\text { "high" inflammatory } \\
\text { biomarkers. }\end{array}$ & $\begin{array}{l}\text { Rapaport et } \\
\text { al., } 2016\end{array}$ \\
\hline $\begin{array}{l}\text { Systematic review; } \\
\text { aged adults or elder } \\
\text { subjects }\end{array}$ & $\begin{array}{l}\text { Ten out of the fourteen RCTs reviewed } \\
\text { showed a positive outcome on at least } \\
\text { one domain of cognitive function (working } \\
\text { memory, executive function, verbal } \\
\text { memory, short-term memory, perceptual } \\
\text { speed, etc.). }\end{array}$ & $\begin{array}{l}\text { Omega-3 supplementation } \\
\text { might have a positive } \\
\text { effect on cognitive } \\
\text { function. Long chain } \\
\text { polyunsaturated fatty } \\
\text { acids could be used as a } \\
\text { preventive or therapeutic } \\
\text { tool for cognitive decline } \\
\text { in aged or elder adults. }\end{array}$ & $\begin{array}{l}\text { Martí et al., } \\
2019\end{array}$ \\
\hline Review & $\begin{array}{l}\text { Preclinical investigations demonstrate that } \\
\text { dietary consumption of DHA provided either } \\
\text { before or after mild traumatic brain injury } \\
\text { (mTBI) improves functional outcomes, such } \\
\text { as spatial learning and memory. }\end{array}$ & $\begin{array}{l}\text { Additional clinical research } \\
\text { in humans is needed to } \\
\text { confirm the promising } \\
\text { results reported in the } \\
\text { preclinical literature. }\end{array}$ & $\begin{array}{l}\text { Barrett et al., } \\
2014\end{array}$ \\
\hline Review & $\begin{array}{l}\text { Animal studies consistently demonstrated } \\
\text { that both prophylactic and therapeutic use } \\
\text { of n-3FA decreases axonal and neuronal } \\
\text { damage, inflammation, and apoptosis and } \\
\text { normalises BDNF and neurotransmitter } \\
\text { levels. }\end{array}$ & $\begin{array}{l}\text { n-3FA may be an effective } \\
\text { nutrient to counter the } \\
\text { negative long-term effects } \\
\text { of TBI. }\end{array}$ & Tipton, 2015 \\
\hline $\begin{array}{l}\text { Randomised, double- } \\
\text { blind, placebo- } \\
\text { controlled, parallel } \\
\text { design, } 81 \text { National } \\
\text { Collegiate Athletic } \\
\text { Association Division } \\
\text { I American football } \\
\text { athletes }\end{array}$ & $\begin{array}{l}\text { Irrespective of a dose, supplemental DHA } \\
\text { likely attenuated serum neurofilament } \\
\text { light (NFL) coincident with increases in } \\
\text { serum NFL by likely small and moderate } \\
\text { magnitude. }\end{array}$ & $\begin{array}{l}\text { Findings from this } \\
\text { study suggesting a } \\
\text { neuroprotective effect of } \\
\text { DHA supplementation. }\end{array}$ & $\begin{array}{l}\text { Oliver et al., } \\
2016\end{array}$ \\
\hline Review & $\begin{array}{l}\text { Nutrients (creatine and omega-3 FAs) } \\
\text { and nutraceuticals (curcumin) have the } \\
\text { potential to act on multiple mechanisms } \\
\text { within the complex neurochemical and } \\
\text { neurometabolic sequelae that occur } \\
\text { subsequent to concussive and sub- } \\
\text { concussive impacts. }\end{array}$ & $\begin{array}{l}\text { Additional research is } \\
\text { necessary to determine } \\
\text { the safety and efficacy } \\
\text { of the use of nutritional } \\
\text { interventions. }\end{array}$ & $\begin{array}{l}\text { Oliver et al., } \\
2018\end{array}$ \\
\hline
\end{tabular}


Baltic Journal of Health and Physical Activity 2020; 12 (3): 114-135

Journal of Gdansk University of Physical Education and Sport

e-ISSN 2080-9999

Table 3. Impact of protein on the cognitive function

\begin{tabular}{|c|c|c|c|}
\hline $\begin{array}{l}\text { Subjects and } \\
\text { methods }\end{array}$ & Results & Conclusion & References \\
\hline $\begin{array}{l}6 \text { women and } 7 \text { men } \\
\text { participated in two } \\
\text { trials of rest in the } \\
\text { heat ( } T a=34.4+/- \\
1.8 \text { degrees) }\end{array}$ & $\begin{array}{l}\text { Cycle time to exhaustion increased during BCAA } \\
\text { for men and women. }\end{array}$ & $\begin{array}{l}\text { Indicate BCAA supplementation } \\
\text { prolongs moderate exercise } \\
\text { performance in the heat. }\end{array}$ & $\begin{array}{l}\text { Mittleman } \\
\text { et al., } 1998\end{array}$ \\
\hline $\begin{array}{l}\text { Meta-analysis } \\
\text { includes } 31 \text { primary } \\
\text { trials }\end{array}$ & $\begin{array}{l}\text { BCAA had no effect on central fatigue. However, } \\
\text { a significant reduction was detected in the } \\
\text { lactate levels. BCAA supplementation had } \\
\text { beneficial effects on ammonia, glucose, FFA, and } \\
\text { CK, but had no effects on LDH. }\end{array}$ & $\begin{array}{l}\text { BCAA supplementation did not have } \\
\text { any effect on the feeling of fatigue; } \\
\text { however, it led to a favourable } \\
\text { effect on fatigue substances, energy } \\
\text { metabolites and muscle soreness } \\
\text { substances. Therefore, it can be } \\
\text { concluded that the ingestion of } \\
\text { the BCAA can play a helpful role in } \\
\text { the enhancement of the exercise } \\
\text { performance. }\end{array}$ & $\begin{array}{l}\text { Hormoznejad } \\
\text { et al., } 2019\end{array}$ \\
\hline Review & $\begin{array}{l}\text { Tryptophan can stimulate brain serotonin and } \\
\text { has been shown to improve memory. }\end{array}$ & $\begin{array}{l}\text { The role of 5-HT in human cognition, } \\
\text { reduced 5-HT function could } \\
\text { be directly linked to cognitive } \\
\text { disturbances in certain conditions, } \\
\text { such as in depression and } \\
\text { Alzheimer's Disease. }\end{array}$ & $\begin{array}{l}\text { Schmitt } \\
\text { et al., } 2006\end{array}$ \\
\hline $\begin{array}{l}\text { Randomised, } \\
\text { placebo-controlled, } \\
\text { parallel trial, } 59 \\
\text { mentally and } \\
\text { physically healthy } \\
\text { women aged } 45-65 \\
\text { years }\end{array}$ & $\begin{array}{l}\text { Emotional processing was significantly } \\
\text { changed by supplementation, exhibiting a } \\
\text { shift in bias away from negative stimuli. When } \\
\text { the supplement was taken } 60-90 \text { min before } \\
\text { bedtime, a feeling of happiness before going to } \\
\text { bed was consistently reported. }\end{array}$ & $\begin{array}{l}\text { Daily consumption of a low-dose } \\
\text { supplement containing bioavailable } \\
\text { tryptophan may have beneficial } \\
\text { effects on emotional and cognitive } \\
\text { functions. }\end{array}$ & $\begin{array}{l}\text { Mohajeri } \\
\text { et al., } 2015\end{array}$ \\
\hline $\begin{array}{l}8 \text { healthy male } \\
\text { volunteers (age } 32 \pm \\
11 \text { years), in a warm } \\
\text { environment }\left(30^{\circ} \mathrm{C}\right)\end{array}$ & $\begin{array}{l}\text { Supplementation of } 150 \mathrm{mg} / \mathrm{kg} \text { bw of tyrosine } \\
\text { one hour prior to exercise was associated with } \\
\text { prolonged performance capacity in heat. }\end{array}$ & $\begin{array}{l}\text { Acute tyrosine supplementation is } \\
\text { associated with increased endurance } \\
\text { capacity in the heat in moderately } \\
\text { trained subjects. The availability } \\
\text { of tyrosine, a nutritional dopamine } \\
\text { precursor, can influence the ability } \\
\text { to subjectively tolerate prolonged } \\
\text { submaximal constant-load exercise in } \\
\text { the heat. }\end{array}$ & $\begin{array}{l}\text { Tumilty et al., } \\
2011\end{array}$ \\
\hline
\end{tabular}


Table 3.

\begin{tabular}{|c|c|c|c|}
\hline $\begin{array}{l}\text { For study } 1: 21 \\
\text { participants; } \\
\text { for study } 2: 8 \\
\text { participants in warm } \\
\text { environment }\left(40^{\circ} \mathrm{C}\right)\end{array}$ & $\begin{array}{l}\text { Study } 1 \text { demonstrated that ingestion of a } \\
\text { single dose of } 150 \mathrm{mg} \cdot \mathrm{kg}(-1) \text { body mass TYR } \\
\text { was equally efficient at elevating serum TYR } \\
\text { concentration relative to a double dose. In study } \\
\text { 2, exercise heat stress impaired some aspects of } \\
\text { cognitive function; however, TYR did not alleviate } \\
\text { these decrements. Furthermore, no difference } \\
\text { was observed in any physiological variable } \\
\text { between conditions or trial completion time } \\
\text { between TYR and placebo. }\end{array}$ & $\begin{array}{l}\text { Ingestion of TYR did not influence } \\
\text { cognitive function or physical } \\
\text { performance during exercise heat } \\
\text { stress. }\end{array}$ & $\begin{array}{l}\text { Coull et al., } \\
2016\end{array}$ \\
\hline $\begin{array}{l}20 \text { current or former } \\
\text { male collegiate } \\
\text { athletes (age: } \\
20.5 \pm 1.4 \text { years) }\end{array}$ & $\begin{array}{l}\text { The combination of a low dose of caffeine with } \\
\text { theanine and tyrosine can improve the accuracy } \\
\text { of athletes' movements and reaction time during } \\
\text { a series of gruelling exercises }\end{array}$ & $\begin{array}{l}\text { Supplementation with caffeine, } \\
\text { theanine and tyrosine could } \\
\text { potentially hold ergogenic value for } \\
\text { athletes in sports requiring rapid and } \\
\text { accurate movements. }\end{array}$ & $\begin{array}{l}\text { Zaragoza et } \\
\text { al., } 2019\end{array}$ \\
\hline
\end{tabular}

Table 4. Impact of carbohydrates on the cognitive function

\begin{tabular}{|c|c|c|c|}
\hline $\begin{array}{l}16 \text { resistance-trained } \\
\text { men (age } 23 \pm 4 \\
\text { years) who regularly } \\
\text { ( } \geq 3 \text { day/wk-1) } \\
\text { consumed breakfast }\end{array}$ & $\begin{array}{l}\text { Omission of a pre-exercise breakfast might impair } \\
\text { resistance exercise performance in habitual } \\
\text { breakfast consumers. }\end{array}$ & $\begin{array}{l}\text { Consumption of a high-carbohydrate } \\
\text { meal before resistance exercise } \\
\text { might be a prudent strategy to help } \\
\text { maximise performance. }\end{array}$ & $\begin{array}{l}\text { Bin } \\
\text { Naharudin } \\
\text { et al., } 2019\end{array}$ \\
\hline $\begin{array}{l}20 \text { participants } \\
\text { (60-80-year olds) }\end{array}$ & $\begin{array}{l}\text { Glucose administration enhances specifically } \\
\text { memory tasks. }\end{array}$ & $\begin{array}{l}\text { A boost in performance after } \\
\text { glucose ingestion was particularly } \\
\text { seen in the episodic memory } \\
\text { domain. }\end{array}$ & $\begin{array}{l}\text { Riby et al., } \\
2004\end{array}$ \\
\hline Review article & $\begin{array}{l}\text { Reduction in exposure to/consumption of refined } \\
\text { 'foods,' including carbohydrates, may be critical } \\
\text { in preventing or treating metabolic-related } \\
\text { cognitive deficits. CHO ingestion, regardless of } \\
\text { its type, tends to improve cognitive performance } \\
\text { throughout exercise. }\end{array}$ & $\begin{array}{l}\text { Consumption of refined } \\
\text { carbohydrates should be reduced. }\end{array}$ & $\begin{array}{l}\text { Hawkins } \\
\text { et al., } 2018\end{array}$ \\
\hline $\begin{array}{l}85 \text { recreationally } \\
\text { active males }\end{array}$ & $\begin{array}{l}\text { The ingestion of maple products and the } \\
\text { commercial sports drink led to a lesser increase in } \\
\text { glycaemia than glucose ingestion. CHO ingestion, } \\
\text { when compared to water, induced a slight } \\
\text { reduction in reaction times on the cognitive task, } \\
\text { especially in the switching trials. CHO ingestion } \\
\text { had no impact on cerebral oxygenation. }\end{array}$ & $\begin{array}{l}\text { CHO ingestion, regardless of its } \\
\text { type, tends to improve cognitive } \\
\text { performance throughout exercise, } \\
\text { especially during difficult cognitive } \\
\text { tasks. }\end{array}$ & $\begin{array}{l}\text { Dupuy et al., } \\
2019\end{array}$ \\
\hline Review article & $\begin{array}{l}\text { Hypoglycaemia during exercise could be related to } \\
\text { a reduced delivery of glucose as a substrate to the } \\
\text { brain, and carbohydrate feedings are associated } \\
\text { with enhanced perceived activation and a lowered } \\
\text { perception of effort during intermittent running in } \\
\text { comparison to the ingestion of placebo. }\end{array}$ & $\begin{array}{l}\text { A diet high in carbohydrates and } \\
\text { consumed carbohydrates during } \\
\text { exercise ensures that the substrate } \\
\text { is available to the central and } \\
\text { peripheral centres. }\end{array}$ & $\begin{array}{l}\text { Williams } \\
\text { et al., } 2015\end{array}$ \\
\hline $\begin{array}{l}7 \text { male and } 2 \text { female } \\
\text { endurance-trained } \\
\text { volunteers (age: } 24.0 \\
\pm 3.8 \text { years) }\end{array}$ & $\begin{array}{l}\text { Performance time was significantly improved with } \\
\text { mouth rinsing of } 6.4 \% \text { maltodextrin compared } \\
\text { with water. }\end{array}$ & $\begin{array}{l}\text { Carbohydrate mouth rinse has a } \\
\text { positive effect on } 1 \text {-h time trial } \\
\text { performance. }\end{array}$ & $\begin{array}{l}\text { Carter et al., } \\
2004\end{array}$ \\
\hline 51 students & $\begin{array}{l}\text { Compared with participants who rinsed with } \\
\text { Splenda-based lemonade, those who rinsed with } \\
\text { glucose-based lemonade were faster on trials in } \\
\text { incongruent trials. }\end{array}$ & $\begin{array}{l}\text { Glucose moderates self-control non- } \\
\text { metabolically. }\end{array}$ & $\begin{array}{l}\text { Sanders } \\
\text { et al., } 2012\end{array}$ \\
\hline
\end{tabular}


Table 4.

\begin{tabular}{|c|c|c|c|}
\hline $\begin{array}{l}\text { Subjects and } \\
\text { methods }\end{array}$ & Results & Conclusion & References \\
\hline $\begin{array}{l}7 \text { recreationally } \\
\text { active males }\end{array}$ & $\begin{array}{l}\text { There were no significant differences in distance } \\
\text { covered between trials with mouth rinsing of } 6 \% \\
\text { maltodextrin. }\end{array}$ & $\begin{array}{l}\text { There was no positive effect } \\
\text { of a carbohydrate mouthwash } \\
\text { on running performance of } \\
\text { approximately } 1 \mathrm{~h} \text { duration }\end{array}$ & $\begin{array}{l}\text { Whitham } \\
\text { et al., } 2007\end{array}$ \\
\hline $\begin{array}{l}\text { Study } 1 A \text { : effects } \\
\text { of oral glucose } \\
\text { on performance: } \\
8 \text { male subjects } \\
\text { (age: } 29 \pm 9 \text { years); } \\
\text { cyclists (endurance } \\
\text { training } \geq 2 \text { sessions } \\
\text { per week). Study } \\
2 \mathrm{~A} \text {, the effects of } \\
\text { maltodextrin on } \\
\text { performance: } 6 \\
\text { male and } 2 \text { female } \\
\text { subjects (age } 22 \pm 3 \\
\text { years) }\end{array}$ & $\begin{array}{l}\text { Cyclists completed a cycle time trial significantly } \\
\text { faster when rinsing their mouths with a } 6.4 \% \\
\text { glucose solution compared with a placebo } \\
\text { containing saccharin. Cyclists significantly reduced } \\
\text { the time to complete the cycle time trial when } \\
\text { rinsing their mouths with a } 6.4 \% \text { maltodextrin } \\
\text { solution compared to an artificially sweetened } \\
\text { placebo. }\end{array}$ & $\begin{array}{l}\text { Rinsing with glucose oral exposure } \\
\text { to glucose activated reward-related } \\
\text { brain regions, including the anterior } \\
\text { cingulate cortex and striatum. } \\
\text { Activation of these regions of the } \\
\text { brain may provide a mechanism } \\
\text { to explain the improvement in } \\
\text { exercise performance that is } \\
\text { observed when carbohydrate is } \\
\text { present in the mouth }\end{array}$ & $\begin{array}{l}\text { Chambers } \\
\text { et al., } 2009\end{array}$ \\
\hline $\begin{array}{l}8 \text { endurance-trained } \\
\text { males (age: } 31.4 \pm \\
4.1 \text { years) performed } \\
\text { two } 40-\mathrm{km} \text { cycling } \\
\text { time trials in } 35^{\circ} \mathrm{C}\end{array}$ & $\begin{array}{l}\text { Performance time and mean power output were } \\
\text { similar between treatments when rinsing their } \\
\text { mouths with } 6.5 \% \text { maltodextrin and placebo. }\end{array}$ & $\begin{array}{l}\text { Carbohydrate mouth rinsing } \\
\text { does not improve } \sim 1 \text {-h time } \\
\text { trial performance in hot-humid } \\
\text { conditions, possibly due to a failure } \\
\text { in down-regulating RPE, which } \\
\text { may be influenced more by severe } \\
\text { thermal and cardiovascular strain. }\end{array}$ & $\begin{array}{l}\text { Cramaer } \\
\text { et al., } 2015\end{array}$ \\
\hline Review article & $\begin{array}{l}\text { Rinsing the mouth with a } 6-8 \% \text { CHO solution for } \\
10 \text { seconds improved physical performance in } \\
\text { high-intensity prolonged and intermittent exercise } \\
\text { shorter or equal to } 60-90 \text { min duration. }\end{array}$ & $\begin{array}{l}\text { Rinsing the mouth with a } 6-8 \% \\
\mathrm{CHO} \text { solution for } 10 \text { seconds in } \\
\text { exercises shorter or equal to } 60-90 \\
\text { min duration is recommended. }\end{array}$ & $\begin{array}{l}\text { Pomportes } \\
\text { et al., } 2020\end{array}$ \\
\hline $\begin{array}{l}\text { Double-blind, } \\
\text { placebo-controlled, } \\
\text { within-subjects } \\
\text { crossover design, } 50 \\
\text { college-aged young } \\
\text { adults }\end{array}$ & $\begin{array}{l}\text { Participants demonstrated longer reaction times in } \\
\text { the Flanker task after rinsing their mouths with the } \\
\text { carbohydrate mouth rinse, relative to pretest. No } \\
\text { differences in reaction time were observed for the } \\
\text { placebo control condition. }\end{array}$ & $\begin{array}{l}\text { Carbohydrate mouth rinses do } \\
\text { not appear to alter motor speed, } \\
\text { inhibition, or sustained attention } \\
\text { as compared to a placebo control } \\
\text { in non-physically-fatigued college- } \\
\text { aged adults. }\end{array}$ & $\begin{array}{l}\text { Chandler } \\
\text { et al., } 2020\end{array}$ \\
\hline $\begin{array}{l}\text { Eleven male subjects } \\
\text { (age } 22 \pm 2 \text { years) }\end{array}$ & $\begin{array}{l}\text { Nasal spray was shown to substantially enhance } \\
\text { endurance performance, probably due to the } \\
\text { activation of the olfactory pathway and/or extra- } \\
\text { oral sweet-taste receptors. }\end{array}$ & $\begin{array}{l}\text { Nasal spray enhances endurance } \\
\text { performance, which indicates a } \\
\text { novel administration route. The } \\
\text { higher activity in sensory brain } \\
\text { cortices probably elicited the } \\
\text { ergogenic effect. }\end{array}$ & $\begin{array}{l}\text { De Pauw } \\
\text { et al., } 2017\end{array}$ \\
\hline
\end{tabular}

In many studies, considerable attention has been paid to the role of polyunsaturated fatty acids (PUFA) in brain functions. Arachidonic acid (AA) and docosahexaenoic acid (DHA) are the main omega-6 and omega-3 long chain PUFA found in the brain. Both long chain PUFA have pivotal roles in brain physiology as they regulate fundamental neurobiological processes, in particular the ones involved in cognition and mood [64,66] (Table 2). Due to the limited capacity of the brain to synthesise long chain PUFA, preformed DHA can be provided by dietary supply of oily fish. Hence, increased consumption of DHA-rich products results in a partial replacement of AA by DHA in brain cell membranes [66]. Conversely, a lower omega-3 PUFA intake leads to lower brain levels of DHA with increased AA levels. Dietary DHA is indispensable for maintaining membrane ionic permeability and the function of transmembrane receptors that support synaptic transmission and cognitive abilities. Omega-3 fatty acids also activate energy-generating metabolic pathways that subsequently affect molecules such as brain-derived neurotrophic factor (BDNF) and insulin-like growth factor 
Dietary DHA is indispensable for maintaining membrane ionic permeability and the function of transmembrane receptors that support synaptic transmission and cognitive abilities. Omega-3 fatty acids also activate energy-generating metabolic pathways that subsequently affect molecules such as brain-derived neurotrophic factor (BDNF) and insulin-like growth factor 1 (IGF1). BDNF and IGF1 acting at presynaptic and postsynaptic receptors can activate signalling systems, such as the mitogen-activated protein kinase (MAPK) and calcium/ calmodulin-dependent protein kinase II (CaMKII) systems, which facilitate synaptic transmission and support long-term potentiation that is associated with learning and memory [2]. DHA dietary supplementation has been found to elevate levels of hippocampal BDNF and enhance cognitive function in rodent models of brain trauma. DHA might enhance cognitive abilities by facilitating synaptic plasticity and/or enhancing synaptic membrane fluidity; it might also act through its effects on metabolism, as DHA stimulates glucose utilization and mitochondrial function, reducing oxidative stress (OS). Most of the studies in humans have been directed at evaluating the effects of omega-3 fatty acids on reducing the cognitive deficit that is associated with psychiatric disorders [2]. N-3 long chain PUFAs could be used as a preventive tool for cognitive decline in aged or elder adults or as a therapeutic measure in subjects with cognitive decline [68] (Table 2).

In spite of the large variability in the design of experiments to evaluate the action of different dietary elements on cognitive abilities, there is a consensus that a deficiency of omega-3 fatty acids in rodents results in impaired learning and memory. Dietary deficiency of omega-3 fatty acids in humans has been associated with an increased risk of several mental disorders, including attention-deficit disorder, dyslexia, dementia, depression, bipolar disorder and schizophrenia [69].

Abnormal omega-3 PUFA levels have been extensively described in both the peripheral tissues and in the brain of patients with mood disorders or cognitive decline, leading to a large number of randomised control trials (RCTs) aiming at evaluating the effectiveness of long chain omega-3 PUFA dietary supplementation on mood and cognitive disorders $[65,70]$ (Table $2)$. It is important to note that several RCTs performed in patients with depressive disorders revealed an additional effect of long chain omega-3 PUFA supplementation to antidepressant treatments [71] (Table 2). Of note, a recent study has identified that depressive patients presenting a high level of inflammatory markers are more responsive to long chain omega-3 PUFA supplementation [72] (Table 2). This observation is highly relevant as these PUFA are potent regulators of inflammation, and inflammation is a crucial component of mood disorders [65].

There is still no evidence if omega-3 fatty acid supplementation would improve cognitive functions in athletes, and it is not known how/if this would translate into improved athletic performance. Anima $l$ and preclinical investigations demonstrate that dietary consumption of DHA provided either before or after mild traumatic brain injury (mTBI) improves functional outcomes, such as spatial learning and memory $[73,74,75]$ (Table 2). A randomised, double-blind, placebo-controlled trial was conducted to examine the effect of differing doses of DHA on serum neurofilament light (NFL), a biomarker of axonal injury, over the course of a season of American football. Eighty-one National Collegiate Athletic Association Division I American football athletes were assigned to ingest either 2, 4, $6 \mathrm{~g} /$ day of DHA or placebo. DHA supplementation resulted in increased plasma DHA in a dose-dependent manner. Irrespective of the dose, 
supplemental DHA likely attenuated serum NFL coincident with increases in serum NFL by likely small and moderate magnitude. Findings from this study suggest a neuroprotective effect of DHA supplementation [76] (Table 2).

\subsection{PROTEIN}

Important precursors for the brain are also derived from protein intake [3]. The synthesis of important neurotransmitters can be modulated by the availability of their dietary amino acid precursors, e.g. essential amino acid, which is tryptophan, important for serotonin production, a neurotransmitter involved in mood, information processing and cognitive function [77]. The another one is tyrosine, precursor to the catecholamines dopamine, epinephrine and norepinephrine $[1,78]$.

Dietary tryptophan can stimulate brain serotonin and has been shown to improve memory, particularly in individuals with possibly compromised serotonergic activity, leading to cognitive deficits, i.e., women with premenstrual symptoms, stress-vulnerable volunteers and depressed patients [79] (Table 3). It was also shown that tryptophan dietary supplements improved cognition in healthy middleaged women [80]. Dietary supplementation of tryptophan is known to stimulate serotonergic activity and promote sleep, whereas acute tryptophan depletion causes deleterious effects on sleep, which is an important factor in recovery [81]. Serotonin cannot cross the blood-brain barrier; however, tryptophan crosses it via specialised channels and is converted to 5-hydroxyl-tryptophan (5-HTP), which then undergoes further conversion to serotonin [82]. In addition to serotonin, other dietary-derived neurotransmitters, such as glutamate, aspartate, and taurine, are shuttled from surrounding astrocytes to neurons and potentially could be influenced by dietary amino acids [83] (Table 3).

Tyrosine, another dietary compound that has been suggested to potentially exert cognition-enhancing effects, can be found in protein-rich foods, such as dairy, meat, eggs, and nuts [84]. Tyrosine serves as a precursor to the catecholamines, dopamine, epinephrine and norepinephrine. Oral intake of tyrosine causes an increase in adrenaline, noradrenaline and dopamine both in the central nervous system (CNS) and peripherally. The revised central fatigue hypothesis suggests that an increase in the central serotonin to dopamine ratio is associated with fatigue and lethargy [85]. Tumilty et al. showed that tyrosine administration was associated with an increased cycling time to exhaustion in the heat $\left(30^{\circ} \mathrm{C}\right)$ [86] (Table 3). Coull et al. showed that tyrosine supplementation was associated with improved sensors and response time during football-specific tests in hot space. This suggests that tyrosine may improve cognitive function during exposure to stress associated with heat stress [87] (Table 3). In the subsequent scientific studies, they confirmed that physical effort in the heat disturbs some aspects of cognitive functions, but tyrosine supplementation does not reduce these effects [88] (Table 3).

An attempt was made to check the effect of supplementation with a combination of low dose caffeine, theanine and tyrosine on sport-specific cognitive functions in tests where accuracy of movements and reaction time are important. The results of this study indicate that the combination of a low dose of caffeine with theanine and tyrosine can improve the accuracy of athletes' movements and reaction time during a series of gruelling exercises [89] (Table 3). 
Providing a supplementation of branched-chain amino acids (BCAA) results in a rapid elevation of their plasma concentrations and increases their uptake into the brain. Because exercise contributes to an elevation of serotonin in the brain, increasing the plasma concentration ratio of free tryptophan to other large neutral amino acids (LNAA), branched-chain amino acids may reduce central and mental fatigue during and after sustained exercise. Although this is a very interesting concept, there is limited or only circumstantial evidence to suggest that exercise performance in humans can be altered by nutritional manipulation with BCAA supplements [90]. Mittleman et al. studied subjects who performed exercise until exhaustion in the heat $\left(34^{\circ} \mathrm{C}\right)$ and observed a significant improvement in performance after BCAA supplementation [91] (Table 3). This result was not confirmed in another study [92] (Table 3). There is good evidence that brain neurotransmitters can play a role in the development of fatigue during prolonged exercise, but nutritional manipulation of these systems through the provision of amino acids has proven largely unsuccessful [93] (Table 3). Hormoznejad et al. concluded that BCAA supplementation did not have any effect on the feeling of fatigue; however, it led to a favourable effect on fatigue substances, energy metabolites and muscle soreness substances. Therefore, it can be concluded that the ingestion of the BCAA can play a helpful role in the enhancement of the exercise performance [94] (Table 3). Gervasi et al. conducted a randomised double-blind placebo-controlled study with thirty-two untrained, healthy young adults to determine whether the intake of a commercially available BCAA-based supplement, taken according to the manufacturer's recommendations, could affect the rating of perceived exertion (RPE) and performance indexes at the beginning (1d) and end of a 9-week $(9 w)$ scheduled high intensity interval training program. It was suggested that the intake of the BCAA-based commercially available supplement used in this study reduces rating of perceived exertion (RPE) as a likely consequence of an improvement in the serum tryptophan: BCAA ratio. Over time, reduced RPE allows subjects to sustain higher workloads, leading to increased training impulse (TRIMP) and time to exhaustion (TTE) [95] (Table 3).

\subsection{CARBOHYDRATES}

Glucose is the main source of energy for the brain, and a number of studies have demonstrated that an inadequate supply of glucose can result in a significant reduction in mental function, and hypoglycaemia may adversely affect brain function and cognitive performance $[90,96]$. Glucose is required for the synthesis of neurotransmitters such as serotonin, noradrenaline, and acetylcholine [42]. Frontal-lobe functioning is enhanced by glucose, suggesting that effects may be due to an increased supply of glucose to the brain areas involved in memory tasks. Alternatively, or additionally, glucose or a metabolite may activate release of acetylcholine during learning to produce improved memory performance [97]. The brain consumes ca. $130 \mathrm{~g}$ of glucose daily; thus, in a resting state, a large portion of the available glucose will be used by the brain. Glucose is stored in the brain as glycogen in the astrocytes and can be degraded in response to sudden increases in energy demand such as periods of increased neuronal activity, during cognitive processes, and in prolonged endurance exercise [12,98-100]. Glucose and glycogen are the primary fuel source of the brain, but lactate also can contribute to fuelling the brain. Especially during periods of high brain activation, astrocytes metabolise glucose, forming lactate as a by-product which will serve as additional fuel [101]. It was concluded that acute glucose administration specifically enhances memory tasks. The effect size was found to be greater for high demanding tasks, especially in adults [102] (Table 4). Although the specific 
effects of glucose in children are poorly described, with one study reporting improved reaction speed, and another reduced attention, the beneficial effects of breakfast on school performance may be related to adequate energy supply to the brain under conditions of sustained cognitive demand $[46,103,104]$.

Evidence from positron emission tomography suggests that increased neural activity (e.g., the learning of a complex visuospatial motor task and verbal working memory) is associated with increased use of glucose by the brain. After learning a task, use of glucose in extraneous brain areas decreases. Cognitive demand, therefore, seems to be associated with increased glucose metabolism in localised areas of the brain and consistent with the notion that cognitively demanding situations can deplete the brain of glucose. Subjects with higher levels of blood glucose and good glucose tolerance (i.e., ability to transport glucose from the bloodstream to the brain) should respond most efficiently to the demand of cognitive tasks. Widom et al. found that the threshold for impairment of cognitive tasks was in the range of 2.2 to $2.8 \mathrm{mmol} / \mathrm{L}$. However, some individuals maintained normal performance at below $2.2 \mathrm{mmol} / \mathrm{L}$, and others showed disruption of function at $4 \mathrm{mmol} / \mathrm{L}$ [105]. It has been suggested that cognitive disruption at higher glucose levels occurs in non-diabetics whose symptoms of hypoglycaemia are relieved by food intake [42]. Lack of glucose availability produces definite impairment of cognitive performance in diabetics of both types and in normal subjects. It follows that enhancing glucose availability through the ingestion of $\mathrm{CHO}$ should ameliorate impairment or indeed enhance performance [42]. There is evidence that impaired glucose regulation is associated with cognitive decline. This impairment is minimal in young people, but increases in older people, which may be associated with other aging processes, leading to reduced brain function [106] (Table 4).

Reduction in consumption of refined 'foods' including carbohydrates (CHO), may be critical in preventing or treating metabolic-related cognitive deficits. $\mathrm{CHO}$ ingestion, regardless of its type, tends to improve cognitive performance throughout exercise [107] (Table 4). The beneficial effect of carbohydrate supplementation during prolonged exercise could also relate to increased (or maintained) substrate delivery for the brain, with a number of studies indicating that hypoglycaemia affects brain function, and cognitive performance. [90]. Carbohydrate supplementation before and during exercise is associated with enhanced brain activation and decreased exercise perception, as well as improved cognitive functions $[108,109]$ (Table 4).

A possible link between the brain and the carbohydrates intake was shown by mouth-rinse studies. The glucose solution presence in the mouth can impact on improved physical and cognitive performance $[110,111]$ (Table 4). A 3\% increase in performance was observed by following the rinsing of a maltodextrin solution around in the mouth before and during exercise [112] (Table 4). Most studies that found a positive effect were carried out in the fasted state. When a carbohydrate mouth rinse was performed in a fed state, no effect on performance in 45-min and 60-min time trials were observed [113,114] (Table 4). The concept of the carbohydrate mouth rinse has been supported by work investigating brain activity following the ingestion of a bolus of glucose and research demonstrating the activation of several brain regions after rinsing the mouth with carbohydrate solutions [110] (Table 4). Those studies highlight a marked increase in brain activation, occurring immediately after carbohydrate enters the mouth, with a second spike in activity observed 10 min following ingestion, presumably occurring as the substrate enters the circulation. There is evidence that any benefit of $\mathrm{CHO}$ 
mouth rinse is lost when exercise is performed in a warm environment [115,116] (Table 4). As was summarised by Pomportes et al. in their review, rinsing the mouth with a $6-8 \%$ CHO solution for 10 seconds improved physical performance in high-intensity prolonged and intermittent exercise shorter or equal to 60-90 min [117] (Table 4). Chandler et al., conducted a double-blind, placebo-controlled trial, within-subjects crossover design with a use of 50 college-aged young adults performing a battery of cognitive tasks both before and after rinsing their mouth for $10 \mathrm{~s}$ with $20 \mathrm{~mL}$ of either a carbohydrate mouth rinse solution or a sensorymatched placebo control solution. Participants demonstrated longer reaction times in the Flanker task after rinsing their mouths with the carbohydrate mouth rinse, relative to pretest. There were observed no differences in the reaction time for the placebo control condition. Carbohydrate mouth rinses do not appear to alter motor speed, inhibition, or sustained attention as compared to a placebo control in non-physically-fatigued college-aged adults [118] (Table 4). Another concept which can be used for greater cognitive efficiency is nasal spray. Nasal spray was shown to substantially enhance endurance performance, probably due to the activation of the olfactory pathway and/or extra-oral sweet-taste receptors [119] (Table 4).

\section{HYDRATION}

The hydration level is one of the most important factors when considering how efficiently the brain is working. On a daily basis, the human body requires between one and seven litres of water to function normally. This demand is increased significantly when undertaking exercise, and varies depending upon environmental temperature and humidity [120]. A decrease in body weight through dehydration of only $1 \%$ can lead to reduced concentration, a less effective memory, increased tension, feelings of anxiety, and an increased experience of fatigue [121] (Table 5). On the other hand, Szinnai et al. showed that cognitivemotor function is preserved during water deprivation in young humans up to a moderate dehydration level of $2.6 \%$ of body weight [122]. Dehydration and hyperthermia cause a temporary unsealing of the blood-brain barrier, which may affect the stability of the brain environment during exercise [123] (Table 5). Dehydrated patients showed higher neuronal activity to achieve the same level of mental performance [124] (Table 5). Wittbrodt et al. conducted the meta-analysis to determine the effect size of dehydration on cognitive performance and influence of experimental design factors. The researchers concluded that dehydration worsens cognitive performance, especially for tasks requiring attention, executive functions and coordination when water deficiencies exceed $2 \%$ of body weight [125] (Table 5). The results could be useful particularly in team sports and in those in which accuracy, decision making and coordination are very important.

\section{OTHER DIETARY COMPONENTS}

A huge group of micronutrients (iron, iodine, zinc, magnesium) and vitamins (vitamin B12, folate, vitamin E, C and D) play an important role in brain functions, and their deficiencies are linked to different cognitive impairments, as well as to potential long-term behavioural changes $[126,127,128,129]$. In addition, there is increasing evidence that some specific nutritional supplements can have a positive impact upon cognitive performance, which is caffeine, creatine, curcumin, cocoa flavanols, nitrate (beetroot juice) and resveratrol $[1,130]$. Some plant products and herbal extracts, such as ginseng, ginkgo biloba, guarana, L-theanine, Rhodiola rosea, mint and sage, are marketed as supplements to enhance performance. In several studies positive effects of these products were shown; however, the literature on their effects on sports performance is scarce [1]. 
Table 5. Impact of water and hydration status on the cognitive function

\begin{tabular}{|c|c|c|c|}
\hline $\begin{array}{l}\text { Subjects and } \\
\text { methods }\end{array}$ & Results & Conclusion & References \\
\hline $\begin{array}{l}10 \text { healthy } \\
\text { adolescents (mean } \\
\text { age }=16.8, \text { five } \\
\text { females) }\end{array}$ & $\begin{array}{l}\text { Participants exerted a higher level of neuronal } \\
\text { activity in order to achieve the same performance } \\
\text { level. }\end{array}$ & $\begin{array}{l}\text { Prolonged states of reduced water } \\
\text { intake may adversely impact } \\
\text { executive functions, such as planning } \\
\text { and visuo-spatial processing }\end{array}$ & $\begin{array}{l}\text { Kempton } \\
\text { et al., } 2011\end{array}$ \\
\hline $\begin{array}{l}33 \text { studies were } \\
\text { identified, providing } \\
280 \text { ES estimates } \\
\text { from } 413 \text { subjects } \\
\text { with DEH ranging } \\
\text { from } 1 \% \text { to } 6 \% \text { BML. }\end{array}$ & $\begin{array}{l}\text { Tasks of executive function, attention and motor } \\
\text { coordination were significantly impaired }(P \leq 0.01) \\
\text { after } D E H \text {, and attention/motor coordination was } \\
\text { different }(P<0.001) \text { from reaction time specific } \\
\text { tasks. }\end{array}$ & $\begin{array}{l}\text { Dehydration worsens cognitive } \\
\text { performance, especially for tasks } \\
\text { involving attention, executive } \\
\text { functions and motor coordination } \\
\text { when water deficits exceed } 2 \% \\
\text { BML. }\end{array}$ & $\begin{array}{l}\text { Wittbrodt et } \\
\text { al., } 2018\end{array}$ \\
\hline
\end{tabular}

\section{LIFESTYLE}

Mitochondrial energy production, which is significant for maintaining neuronal excitability and synaptic function, can be affected by diet and exercise. The combination of certain diets and exercise can have additive effects on synaptic plasticity and cognitive function. ATP produced by mitochondria might activate brain-derived neurotrophic factor (BDNF) and insulin-like growth factor 1 (IGF1), which support synaptic plasticity and cognitive function. Numerous studies have shown that physical activity enhances learning and memory under a variety of conditions $[2,131]$. Physical training seems to be one of the best tools in a possible treatment of cognitively impaired elderly people [132].

The quality and duration of an individual's sleep, including the quality of recovery, is an important factor, which has also been identified to influence brain performance [133]. It has been suggested that the restorative nature of good quality sleep is important for effective training and performance [134]. High quality sleep can help athletes deal with, and adjust to, the emotional, immunological, neurological, and physical stressors that they experience [135]. Evidence suggests that one night of sleep deprivation can diminish waking regional brain activity in the areas that are responsible for alertness, attention, and higher-order cognitive processes [136].

Stress can lead to improved performance through increased focus and strength or can have a negative influence on performance through distraction and decreased fine motor control [137]. Stress may grow the effects of food on mental performance by modulating brain serotonin function. Chronic stress may produce increased serotonin activity, leading to a functional shortage of tryptophan and brain serotonin concentrations [42]. The physical activity activates the body's stress response, the hypothalamic-pituitary-adrenal (HPA) axis, giving effects at a physical and psychological level [138]. One of these physiological responses is the cortisol secretion. Bermejo et al. conducted the trial whose aim was to elucidate the effects of a single bout of high intensity exercise on behavioural (i.e., attention and memory) and physiological (i.e., salivary cortisol) responses and to evaluate the effect of the performance of the cognitive tasks on cortisol levels. They concluded that the effects of stress on cognitive performance depend on the main brain areas responsible 
of cognitive functions (i.e., prefrontal cortex and hippocampus) and the time elapsed between the cessation of exercise and the evaluation of these [139]..

There is an important connection between probiotics, psychobiotics and cognitive and behavioural processes. They include neurological, hormonal, metabolic and immunological signalling pathways and the changes in these systems may result in alterations in behaviour (mood) and cognition (learning and memory). Psychobiotics have been recognised as key factors in affective disorders and the immune system, in addition to their effect including the regulation of neuroimmune regulation and control axes in diseases of the nervous system [140].

\section{CONCLUSIONS}

It is important to understand the importance of factors influencing brain function and cognitive performance, which can be crucial to athletic performance and well-being of athletes. There have been many studies investigating the effect of dietary components on the brain activity. The importance of this data is particularly significant in team sports and in those where accuracy, decision making and coordination are very important.

Assumptions of the Mediterranean diet correlate with better global cognition, episodic memory, a lower risk of cognitive impairment and neurodegenerative diseases. In turn, high-fat and high-sugar diet shows the opposite effect. Omega-3 fatty acids could be used as a preventive tool for cognitive decline in aged or elder adults or as a therapeutic measure in subjects with cognitive decline but there is still insufficiently evidence if omega-3 fatty acid supplementation would improve cognitive functions. Their use in the treatment after mild traumatic brain injury (mTBI) seems to give high hopes. The proper intake of protein is a significant factor in physical performance and may be important in cognitive functions. Tyrosine seems to be potentially effective in inhibition of fatigue under extreme conditions. The results from studies showing the influence of BCAA on cognitive performance are still unclear and more well-controlled studies in exercise science is needed. An appropriate glucose level and the amount of glycogen, which are the primary fuel source for the brain, are the critical factors for brain functions. Carbohydrate supplementation before and during exercise is associated with enhanced brain activation and decreased exercise perception, as well as improved cognitive functions. The counteraction of hypoglycaemia may favourably affect brain function and cognitive performance. Nasal sprays and mouth rinse have an impact on improved physical and, most likely, cognitive performance. Dehydration exceeding $2 \%$ of body weight worsens cognitive performance, especially for tasks requiring attention, executive functions and coordination. Therefore, athletes need to control their hydration level and to replenish the fluids with proper sports drinks.

Finally, it is important to note that much of the cited evidence relates to the general, elderly population or to participants with cognitive disorders; therefore, analogous studies should be carried out among active people. Based on the review of available studies, it should be assumed that proper nutrition is a key factor in physical performance, but it also plays a relevant role in athletes' cognitive performance. In the context of improving or maintaining cognitive functions, it seems advisable to follow the assumptions of the Mediterranean diet, with particular emphasis on the proper supply of vegetables, fruits and vegetable oils, proper hydration with appropriate types of fluids and eating balanced meals, especially breakfast, ensuring the supply of unnecessary macroand micronutrients. 


\section{REFERENCES}

[1] Meeusen R, Decroix L. Nutritional Supplements and the Brain. Int J Sport Nutr Exerc Metab. 2018;28(2):200-211. https://doi.org/10.1123/ijsnem.2017-0314

[2] Gómez-Pinilla F. Brain foods: the effects of nutrients on brain function. Nat Rev Neurosci. 2008;9(7):568-578. https://doi.org/10.1038/nrn2421

[3] LeCoutre J, Schmitt JAJ. Food ingredients and cognitive functions. Curr Opin Clin Nutr Metab Care. 2008;11:706-710. https://doi.org/10.1097/MCO.0b013e32831394a5

[4] Schmitt JAJ, LeCoutre J. Nutrition for cognition. Front Neurosci. 2009;3:88-89.

[5] de Groot RH, Stein AD, Jolles J, et al. Prenatal famine exposure and cognition at age 59 years. Int J Epidemiol. 2011;40(2):327-337. https://doi.org/10.1093/ije/dyq261

[6] Dabelea D, Hanson RL, Lindsay RS, et al. Intrauterine exposure to diabetes conveys risks for type 2 diabetes and obesity: a study of discordant sibships. Diabetes. 2000;49(12):2208-2211. https://doi. org/10.2337/diabetes.49.12.2208

[7] Boney CM, Verma A, Tucker R, Vohr BR. Metabolic syndrome in childhood: association with birth weight, maternal obesity, and gestational diabetes mellitus. Pediatrics. 2005;115(3):e290-e296. https://doi.org/10.1542/peds.2004-1808

[8] Ong ZY, Muhlhausler BS. Maternal "junk-food" feeding of rat dams alters food choices and development of the mesolimbic reward pathway in the offspring. FASEB J. 2011;25(7):2167-2179. https://doi. $\operatorname{org} / 10.1096 / \mathrm{fj} .10-178392$

[9] Gugusheff JR, Ong ZY, Muhlhausler BS. A maternal "junk-food" diet reduces sensitivity to the opioid antagonist naloxone in offspring postweaning. FASEB. J. 2013; 27(3):1275-1284. https://doi. org/10.1096/fj.12-217653

[10] Drover J, Hoffman DR, Castañeda YS, Morale SE, Birch EE. Three randomized controlled trials of early long-chain polyunsaturated Fatty Acid supplementation on means-end problem solving in 9-month-olds. Child Dev. 2009;80(5):1376-1384. https://doi.org/10.1111/j.1467-8624.2009.01339.x

[11] Spencer SJ, Korosi A, Layé S, et al. Food for thought: how nutrition impacts cognition and emotion. npj Sci Food. 2017;1(7). https://doi.org/10.1038/s41538-017-0008-y

[12] Wender R, Brown AM, Fern R, Swanson RA, Farrell K, Ransom BR. Astrocytic glycogen influences axon function and survival during glucose deprivation in central white matter. J Neurosci. 2000;20(18):68046810. https://doi.org/10.1523/JNEUROSCI.20-18-06804.2000

[13] Whitmer RA, Gunderson EP, Barrett-Connor E, Quesenberry CP Jr, Yaffe K. Obesity in middle age and future risk of dementia: a 27 year longitudinal population based study. BMJ. 2005;330(7504):1360 https://doi.org/10.1136/bmj.38446.466238.E0

[14] Jurdak N, Kanarek RB. Sucrose-induced obesity impairs novel object recognition learning in young rats. Physiol Behav. 2009;96(1):1-5. https://doi.org/10.1016/j.physbeh.2008.07.023

[15] Tran DM, Westbrook RF. A high-fat high-sugar diet-induced impairment in place-recognition memory is reversible and training-dependent. Appetite. 2017;110:61-71. https://doi.org/10.1016/j. appet.2016.12.010

[16] Gainey SJ, Kwakwa KA, Bray JK, et al. Short-term high-fat diet (HFD) induced anxiety-like behaviors and cognitive impairment are improved with treatment by Glyburide. Front Behav Neurosci. 2016;10:156. https://doi.org/10.3389/fnbeh.2016.00156

[17] Pyndt Jørgensen B, Hansen JT, Krych L, et al. A possible link between food and mood: dietary impact on gut microbiota and behaviour in BALB/c mice. PLoS One. 2014;9(8):e103398. https://doi. org/10.1371/journal.pone.0103398

[18] Jacka FN, Cherbuin N, Anstey KJ, Butterworth P. Dietary patterns and depressive symptoms over time: examining the relationships with socioeconomic position, health behaviours and cardiovascular risk. PLoS One. 2014;9(1):e87657. https://doi.org/10.1371/journal.pone.0087657

[19] Reichelt AC, Maniam J, Westbrook RF, et al. Dietary-induced obesity disrupts trace fear conditioning and decreases hippocampal reelin expression. Brain Behav Immun. 2015;43:68-75. https://doi. org/10.1016/j.bbi.2014.07.005

[20] Beilharz JE, Maniam J, Morris MJ. Short-term exposure to a diet high in fat and sugar, or liquid sugar, selectively impairs hippocampal-dependent memory, with differential impacts on inflammation. Behav Brain Res. 2016;306:1-7. https://doi.org/10.1016/j.bbr.2016.03.018

[21] Beilharz JE, Maniam J, Morris MJ. Short exposure to a diet rich in both fat and sugar or sugar alone impairs place, but not object recognition memory in rats. Brain Behav Immun. 2014;37:134-141. https://doi.org/10.1016/j.bbi.2013.11.016

[22] De Luca, S. N. et al. Early life overfeeding impairs spatial memory performance by reducing microglial sensitivity to learning. J. Neuroinflammation. 2016;13,(112): n.page. https://doi.org/10.1186/s12974016-0578-7

[23] Almeida-Suhett CP, Graham A, Chen Y, Deuster P. Behavioral changes in male mice fed a high-fat diet are associated with IL-1 $\beta$ expression in specific brain regions. Physiol Behav. 2017;169:130-140. https://doi.org/10.1016/j.physbeh.2016.11.016

[24] Boitard C, Cavaroc A, Sauvant J, et al. Impairment of hippocampal-dependent memory induced by juvenile high-fat diet intake is associated with enhanced hippocampal inflammation in rats. Brain Behav Immun. 2014;40:9-17. https://doi.org/10.1016/j.bbi.2014.03.005

[25] Sobesky JL, D'Angelo HM, Weber MD, et al. Glucocorticoids Mediate short-term high-fat diet induction of neuroinflammatory priming, the NLRP3 inflammasome, and the danger signal HMGB1. eNeuro. 2016;3(4):ENEURO.0113-16.2016. https://doi.org/10.1523/ENEURO.0113-16.2016 
[26] Tantot F, Parkes SL, Marchand AR, et al. The effect of high-fat diet consumption on appetitive instrumental behaviour in rats. Appetite. 2017;108:203-211. https://doi.org/10.1016/j. appet.2016.10.001

[27] Sobesky JL, Barrientos RM, De May HS, et al. High-fat diet consumption disrupts memory and primes elevations in hippocampal IL-1 $\beta$, an effect that can be prevented with dietary reversal or IL-1 receptor antagonism. Brain Behav Immun. 2014;42:22-32. https://doi.org/10.1016/j.bbi.2014.06.017

[28] Frank MG, Miguel ZD, Watkins LR, Maier SF. Prior exposure to glucocorticoids sensitizes the neuroinflammatory and peripheral inflammatory responses to E. coli lipopolysaccharide. Brain Behav Immun. 2010;24(1):19-30. https://doi.org/10.1016/j.bbi.2009.07.008

[29] Frank MG, Hershman SA, Weber MD, Watkins LR, Maier SF. Chronic exposure to exogenous glucocorticoids primes microglia to pro-inflammatory stimuli and induces NLRP3 mRNA in the hippocampus. Psychoneuroendocrinology. 2014;40:191-200. https://doi.org/10.1016/j. psyneuen.2013.11.006

[30] Barrientos RM, Thompson VM, Kitt MM, et al. Greater glucocorticoid receptor activation in hippocampus of aged rats sensitizes microglia. Neurobiol Aging. 2015;36(3):1483-1495. https://doi. org/10.1016/j.neurobiolaging.2014.12.003

[31] Noble EE, Kanoski SE. Early life exposure to obesogenic diets and learning and memory dysfunction. Curr Opin Behav Sci. 2016;9:7-14. https://doi.org/10.1016/j.cobeha.2015.11.014

[32] Morris MJ, Le V, Maniam J. The impact of poor diet and early life stress on memory status. Current Opinion in Behavioral Sciences 2016; 9:144-151. https://doi.org/10.1016/j.cobeha.2016.04.002

[33] Reichelt AC. Adolescent Maturational transitions in the prefrontal cortex and dopamine signaling as a risk factor for the development of obesity and high fat/high sugar diet induced cognitive deficits. Front Behav Neurosci. 2016;10:189. https://doi.org/10.3389/fnbeh.2016.00189

[34] Reichelt AC, Rank MM. The impact of junk foods on the adolescent brain. Birth defects research. 2017; 109:1649-1658. https://doi.org/10.1002/bdr2.1173

[35] Ding B, Xiao R, Ma W, Zhao L, Bi Y, Zhang Y. The association between macronutrient intake and cognition in individuals aged under 65 in China: a cross-sectional study. BMJ Open. 2018;8(1):e018573. https://doi.org/10.1136/bmjopen-2017-018573

[36] Jakobsen LH, Kondrup J, Zellner M, Tetens I, Roth E. Effect of a high protein meat diet on muscle and cognitive functions: a randomised controlled dietary intervention trial in healthy men. Clin Nutr. 2011;30(3):303-311. https://doi.org/10.1016/j.clnu.2010.12.010

[37] Du K, Markus E, Fecych M, Rhodes JS, Beverly JL. Satiety and memory enhancing effects of a highprotein meal depend on the source of protein. Nutritional Neuroscience. 2017;21(4),257-267. https:// doi.org/10.1080/1028415X.2016.1277055

[38] Lehert P, Villaseca P, Hogervorst E, Maki PM, Henderson VW. Individually modifiable risk factors to ameliorate cognitive aging: a systematic review and meta-analysis. Climacteric. 2015;18(5):678-689. https://doi.org/10.3109/13697137.2015.1078106

[39] Singh B, Parsaik AK, Mielke MM, et al. Association of mediterranean diet with mild cognitive impairment and Alzheimer's disease: a systematic review and meta-analysis. J Alzheimers Dis. 2014;39(2):271-282. https://doi.org/10.3233/JAD-130830

[40] van den Brink AC, Brouwer-Brolsma EM, Berendsen AAM, van de Rest O. The Mediterranean, dietary approaches to stop hypertension (DASH), and Mediterranean-DASH intervention for neurodegenerative delay (MIND) diets are associated with less cognitive decline and a lower risk of Alzheimer's Disease - A review. Adv Nutr. 2019;10(6):1040-1065. https://doi.org/10.1093/advances/ nmz054

[41] Ríos-Hernández A, Alda JA, Farran-Codina A, Ferreira-García E, Izquierdo-Pulido M. The Mediterranean diet and ADHD in children and adolescents. Pediatrics. 2017;139(2):e20162027. https://doi.org/10.1542/peds.2016-2027

[42] Dye L, Lluch A, Blundell JE. Macronutrients and mental performance. Nutrition. 2000;16(10):10211034. https://doi.org/10.1016/S0899-9007(00)00450-0

[43] Smith A, Kendrick A, Maben A, Salmon J. Effects of fat content, weight, and acceptability of the meal on postlunch changes in mood, performance, and cardiovascular function. Physiol Behav. 1994;55(3):417-422. https://doi.org/10.1016/0031-9384(94)90094-9

[44] Kaplan RJ, Greenwood CE, Winocur G, Wolever TM. Dietary protein, carbohydrate, and fat enhance memory performance in the healthy elderly. Am J Clin Nutr. 2001;74(5):687-693. https://doi. org/10.1093/ajcn/74.5.687

[45] Cooper SB, Bandelow S, Nevill ME. Breakfast consumption and cognitive function in adolescent schoolchildren. Physiol Behav. 2011;103(5):431-439. https://doi.org/10.1016/j.physbeh.2011.03.018

[46] Benton D, Parker PY. Breakfast, blood glucose, and cognition. Am J Clin Nutr. 1998;67(4):772S-778S. https://doi.org/10.1093/ajcn/67.4.772S

[47] Hoyland A, Dye L, Lawton CL. A systematic review of the effect of breakfast on the cognitive performance of children and adolescents. Nutr Res Rev. 2009;22(2):220-243. https://doi.org/10.1017/ S0954422409990175

[48] Cooper SB, Bandelow S, Nute ML, Morris JG, Nevill ME. Breakfast glycaemic index and cognitive function in adolescent school children. Br J Nutr. 2012;107(12):1823-1832. https://doi.org/10.1017/ S0007114511005022

[49] Cooper SB, Bandelow S, Nute ML, Morris JG, Nevill ME. Breakfast glycaemic index and exercise: Combined effects on adolescents' cognition. Physiol Behav. 2015;139:104-111. https://doi. org/10.1016/j.physbeh.2014.11.024

[50] Philippou E, Constantinou M. The influence of glycemic index on cognitive functioning: A systematic review of the evidence. Adv Nutr. 2014;5(2):119-130. https://doi.org/10.3945/an.113.004960 
[51] Murphy JM, Pagano ME, Nachmani J, Sperling P, Kane S, Kleinman RE. The relationship of school breakfast to psychosocial and academic functioning: cross-sectional and longitudinal observations in an inner-city school sample. Arch Pediatr Adolesc Med. 1998;152(9):899-907. https://doi.org/10.1001/ archpedi.152.9.899

[52] Nilsson A, Radeborg K, Björck I. Effects of differences in postprandial glycaemia on cognitive functions in healthy middle-aged subjects. Eur J Clin Nutr. 2009;63(1):113-120. https://doi.org/10.1038/ sj.ejcn.1602900

[53] Komiyama T, Sudo M, Okuda N, et al. Cognitive function at rest and during exercise following breakfast omission. Physiol Behav. 2016;157:178-184. https://doi.org/10.1016/j.physbeh.2016.02.013

[54] Bin Naharudin MN, Yusof A, Shaw H, Stockton M, Clayton DJ, James LJ. Breakfast Omission reduces subsequent resistance exercise performance. J Strength Cond Res. 2019;33(7):1766-1772. https:// doi.org/10.1519/JSC.0000000000003054

[55] Svennerholm L. Distribution and fatty acid composition of phosphoglycerides in normal human brain. J Lipid Res. 1968;9(5):570-579

[56] Cetin I, Koletzko B. Long-chain omega-3 fatty acid supply in pregnancy and lactation. Curr Opin Clin Nutr Metab Care. 2008;11(3):297-302. https://doi.org/10.1097/MCO.0b013e3282f795e6

[57] Koletzko B, Lien E, Agostoni C, et al. The roles of long-chain polyunsaturated fatty acids in pregnancy, lactation and infancy: review of current knowledge and consensus recommendations. J Perinat Med. 2008;36(1):5-14. https://doi.org/10.1515/JPM.2008.001

[58] Simmer K, Patole SK, Rao SC. Long-chain polyunsaturated fatty acid supplementation in infants born at term. Cochrane Database Syst Rev. 2008;(1):CD000376. https://doi.org/10.1002/14651858. CD000376.pub2

[59] Eilander A, Hundscheid DC, Osendarp SJ, Transler C, Zock PL. Effects of n-3 long chain polyunsaturated fatty acid supplementation on visual and cognitive development throughout childhood: a review of human studies. Prostaglandins Leukot Essent Fatty Acids. 2007;76(4):189-203. https://doi. org/10.1016/j.plefa.2007.01.003

[60] Issa AM, Mojica WA, Morton SC, et al. The efficacy of omega-3 fatty acids on cognitive function in aging and dementia: a systematic review. Dement Geriatr Cogn Disord 2006; 21:88-96. https://doi. org/10.1159/000090224

[61] Richardson AJ. Omega-3 fatty acids in ADHD and related neurodevelopmental disorders. Int Rev Psychiatry. 2006;18(2):155-172. https://doi.org/10.1080/09540260600583031

[62] Lin PY, Su KP. A meta-analytic review of double-blind, placebo-controlled trials of antidepressant efficacy of omega-3 fatty acids. J Clin Psychiatry. 2007;68(7):1056-1061. https://doi.org/10.4088/ JCP.v68n0712

[63] Montgomery P, Richardson AJ. Omega-3 fatty acids for bipolar disorder. Cochrane Database Syst Rev. 2008;(2):CD005169. https://doi.org/10.1002/14651858.CD005169.pub2

[64] Joy CB, Mumby-Croft R, Joy LA. Polyunsaturated fatty acid supplementation for schizophrenia. Cochrane Database Syst Rev. 2006;2006(3):CD001257. https://doi.org/10.1002/14651858.CD001257. pub2

[65] Bazinet RP, Layé S. Polyunsaturated fatty acids and their metabolites in brain function and disease. Nat Rev Neurosci. 2014;15(12):771-785. https://doi.org/10.1038/nrn3820

[66] Joffre C, Nadjar A, Lebbadi M, Calon F, Laye S. n-3 LCPUFA improves cognition: the young, the old and the sick. Prostaglandins Leukot Essent Fatty Acids. 2014;91(1-2):1-20. https://doi.org/10.1016/j. plefa.2014.05.001

[67] Joffre C, Grégoire S, De Smedt V, et al. Modulation of brain PUFA content in different experimental models of mice. Prostaglandins Leukot Essent Fatty Acids. 2016;114:1-10. https://doi.org/10.1016/j. plefa.2016.09.003

[68] Martí Del Moral A, Fortique F. Omega-3 fatty acids and cognitive decline: A systematic review. Omega-3 y deterioro cognitivo: una revisión sistemática. Nutr Hosp. 2019;36(4):939-949. https:// doi.org/10.20960/nh.02496

[69] Freeman MP, Hibbeln JR, Wisner KL, et al. Omega-3 fatty acids: evidence basis for treatment and future research in psychiatry [published correction appears in J Clin Psychiatry. 2007 Feb;68(2):338] J Clin Psychiatry. 2006;67(12):1954-1967. https://doi.org/10.4088/JCP.v67n1217

[70] Saunders EF, Ramsden CE, Sherazy MS, Gelenberg AJ, Davis JM, Rapoport SI. Omega-3 and Omega-6 Polyunsaturated fatty acids in bipolar disorder: A review of biomarker and treatment studies. J Clin Psychiatry. 2016;77(10):e1301-e1308. https://doi.org/10.4088/JCP.15r09925

[71] Bozzatello P, Brignolo E, De Grandi E, Bellino S. Supplementation with Omega-3 fatty acids in psychiatric disorders: A review of literature data. J Clin Med. 2016;5(8):67. https://doi.org/10.3390/jcm5080067

[72] Rapaport MH, Nierenberg AA, Schettler PJ, et al. Inflammation as a predictive biomarker for response to Omega-3 fatty acids in major depressive disorder: A proof-of-concept study. Mol Psychiatry. 2016;21(1):71-79. https://doi.org/10.1038/mp.2015.22

[73] Barrett EC, McBurney MI, Ciappio ED. $\omega$-3 fatty acid supplementation as a potential therapeutic aid for the recovery from mild traumatic brain injury/concussion. Adv Nutr. 2014;5(3):268-277. https:// doi.org/10.3945/an.113.005280

[74] Tipton KD. Nutritional support for exercise-induced injuries. Sports Med. 2015;45 Suppl 1:S93-S104. https://doi.org/10.1007/s40279-015-0398-4

[75] Oliver JM, Anzalone AJ, Turner SM. Protection before impact: The potential neuroprotective role of nutritional supplementation in sports-related head trauma. Sports Med. 2018;48(Suppl 1):39-52. https://doi.org/10.1007/s40279-017-0847-3

[76] Oliver JM, Jones MT, Kirk KM, et al. Effect of docosahexaenoic acid on a biomarker of head trauma in American football. Med Sci Sport Exerc. 2016;48(6):974-982. https://doi.org/10.1007/s40279-017-0847-3 
[77] Young SN. Behavioral effects of dietary neurotransmitter precursors: basic and clinical aspects Neurosci Biobehav Rev. 1996;20(2):313-323. https://doi.org/10.1016/0149-7634(95)00022-4

[78] Wahl D, Cogger VC, Solon-Biet SM, et al. Nutritional strategies to optimise cognitive function in the aging brain. Ageing Res Rev. 2016;31:80-92. https://doi.org/10.1016/j.arr.2016.06.006

[79] SchmittJA, Wingen M, Ramaekers JG, Evers EA, Riedel WJ. Serotonin and human cognitive performance. Curr Pharm Des. 2006;12(20):2473-2486. https://doi.org/10.2174/138161206777698909

[80] Mohajeri MH, Wittwer J, Vargas K, et al. Chronic treatment with a tryptophan-rich protein hydrolysate improves emotional processing, mental energy levels and reaction time in middleaged women. Br J Nutr. 2015;113(2):350-365. https://doi.org/10.1017/S0007114514003754

[81] Melancon MO, Lorrain D, Dionne IJ. Exercise and sleep in aging: emphasis on serotonin. Pathol Biol (Paris). 2014;62(5):276-283. https://doi.org/10.1016/j.patbio.2014.07.004

[82] Shabbir F, Patel A, Mattison C, et al. Effect of diet on serotonergic neurotransmission in depression. Neurochem Int. 2013;62(3):324-329. https://doi.org/10.1016/j.neuint.2012.12.014

[83] Gundersen V, Storm-Mathisen J, Bergersen LH. Neuroglial transmission. Physiol Rev. 2015;95(3):695726. https://doi.org/10.1152/physrev.00024.2014

[84] van de Rest O, Bloemendaal M, de Heus R, Aarts E. Dose-dependent effects of oral tyrosine administration on plasma tyrosine levels and cognition in aging. Nutrients. 2017;9(12):1279. Published 2017 Nov 23. https://doi.org/10.3390/nu9121279

[85] Meeusen R, Roelands B. Fatigue: Is it all neurochemistry?. Eur J Sport Sci. 2018;18(1):37-46. https://doi.org/10.1080/17461391.2017.1296890

[86] Tumilty L, Davison G, Beckmann M, Thatcher R. Oral tyrosine supplementation improves exercise capacity in the heat. Eur J Appl Physiol. 2011;111(12):2941-2950. https://doi.org/10.1007/s00421011-1921-4

[87] Coull NA, Watkins SL, Aldous JW, et al. Effect of tyrosine ingestion on cognitive and physical performance utilising an intermittent soccer performance test (iSPT) in a warm environment. Eur J Appl Physiol. 2015;115(2):373-386. https://doi.org/10.1007/s00421-014-3022-7

[88] Coull N, Chrismas B, Watson P, Horsfall R, Taylor L. Tyrosine Ingestion and its effects on cognitive and physical performance in the heat. Med Sci Sports Exerc. 2016;48(2):277-286. https://doi. org/10.1249/MSS.0000000000000757

[89] Zaragoza J, Tinsley G, Urbina S, et al. Effects of acute caffeine, theanine and tyrosine supplementation on mental and physical performance in athletes. J Int Soc Sports Nutr. 2019;16(56): n. pag. doi:10.1186/s12970-019-0326-3

[90] Meeusen R. Exercise, nutrition and the brain. Sports Med. 2014;44 Suppl 1(Suppl 1):S47-S56. https://doi.org/10.1007/s40279-014-0150-5

[91] Mittleman KD, Ricci MR, Bailey SP. Branched-chain amino acids prolong exercise during heat stress in men and women. Med Sci Sports Exerc. 1998;30(1):83-91. https://doi.org/10.1097/00005768199801000-00012

[92] Watson P, Shirreffs SM, Maughan RJ. The effect of acute branched-chain amino acid supplementation on prolonged exercise capacity in a warm environment. Eur J Appl Physiol. 2004;93(3):306-314. https://doi.org/10.1007/s00421-004-1206-2

[93] Meeusen R, Watson P. Amino acids and the brain: Do they play a role in “central fatigue”? Int J Sport Nutr Exerc Metab. 2007;17:S37-S46. https://doi.org/10.1123/ijsnem.17.s1.s37

[94] Hormoznejad R, Javid, AZ, Mansoori A. Effect of BCAA supplementation on central fatigue, energy metabolism substrate and muscle damage to the exercise: a systematic review with meta-analysis. Sport Sci Health. 2019;15, 265-279. DOI:10.1007/s11332-019-00542-4

[95] Gervasi M, Sisti D, Amatori S, et al. Effects of a commercially available branched-chain amino acidalanine-carbohydrate-based sports supplement on perceived exertion and performance in high intensity endurance cycling tests. J Int Soc Sport Nutr. 2020 Jan;17(1):6. https://doi.org/10.1186/ s12970-020-0337-0

[96] Amiel SA, Archibald HR, Chusney G, Williams AJ, Gale EA. Ketone infusion lowers hormonal responses to hypoglycaemia: evidence for acute cerebral utilization of a non-glucose fuel. Clin Sci (Lond). 1991;81(2):189-194. https://doi.org/10.1042/cs0810189

[97] Korol DL, Gold PE. Glucose, memory, and aging. Am J Clin Nutr. 1998;67(4):764S-771S. https:// doi.org/10.1093/ajcn/67.4.764S

[98] Reinmuth OM, Kogure K, Scheinberg P, Shimojyo S. Total cerebral blood flow and metabolism in human brain stem disease. Neurology. 1968;18(3):280-281

[99] Brown AM, Ransom BR. Astrocyte glycogen and brain energy metabolism. Glia. 2007;55(12):12631271. https://doi.org/10.1002/glia.20557

[100] Matsui T, Soya S, Okamoto M, Ichitani Y, Kawanaka K, Soya H. Brain glycogen decreases during prolonged exercise [published correction appears in J Physiol. 2011 Aug 15;589(Pt 16):4079] J Physiol. 2011;589(Pt 13):3383-3393. https://doi.org/10.1113/jphysiol.2010.203570

[101] Dienel GA. Brain lactate metabolism: the discoveries and the controversies. J Cereb Blood Flow Metab. 2012;32(7):1107-1138. https://doi.org/10.1038/jcbfm.2011.175

[102] Riby LM, Meikle A, Glover C. The effects of age, glucose ingestion and gluco-regulatory control on episodic memory. Age Ageing. 2004;33(5):483-487. https://doi.org/10.1093/ageing/afh173

[103] Wesnes KA, Pincock C, Richardson D, et al. Breakfast reduces declines in attention and memory over the morning in schoolchildren. Appetite. 2003;41(3):329-331. https://doi.org/10.1016/j.appet.2003.08.009

[104] Rampersaud GC, Pereira MA, Girard BL, Adams J, Metzl JD. Breakfast habits, nutritional status, body weight, and academic performance in children and adolescents. J Am Diet Assoc. 2005;105(5):743762. https://doi.org/10.1016/j.jada.2005.02.007 
[105] Widom B, Simonson DC. Glycemic control and neurophysiologic function during hypoglycemia in patients with insulin dependent diabetes mellitus. Annu Rev 1990;112:904. https://doi. org/10.7326/0003-4819-112-12-904

[106] Messier C. Glucose improvement of memory: A review. Eur J Pharmacol. 2004;490(1-3):33-57. https://doi.org/10.1016/j.ejphar.2004.02.043

[107] Hawkins AW, Keirns NG, Helms Z. Carbohydrates and cognitive function. Current Opinion in Clinical Nutrition and Metabolic Care. 2018;21(4):302-307. https://doi.org/10.1097/MC0.0000000000000471

[108] Williams C, Rollo I. Carbohydrate nutrition and team sport performance. Sports Med. 2015;45 Suppl 1(Suppl 1):S13-S22. https://doi.org/10.1007/s40279-015-0399-3

[109] Dupuy O, Tremblay J. Impact of carbohydrate ingestion on cognitive flexibility and cerebral oxygenation during high-intensity intermittent exercise: A comparison between maple products and usual carbohydrate solutions. Nutrients. 2019;11(9):2019. https://doi.org/10.3390/nu11092019

[110] Chambers ES, Bridge MW, Jones DA. Carbohydrate sensing in the human mouth: Effects on exercise performance and brain activity. J Physiol. 2009;587(Pt 8):1779-1794. https://doi.org/10.1113/ jphysiol.2008.164285

[111] Sanders MA, Shirk SD, Burgin CJ, Martin LL. The gargle effect: rinsing the mouth with glucose enhances self-control. Psychol Sci. 2012;23(12):1470-1472. https://doi.org/10.1177/0956797612450034

[112] Carter JM, Jeukendrup AE, Jones DA. The effect of carbohydrate mouth rinse on 1-h cycle time trial performance. Med Sci Sports Exerc. 2004;36(12):2107-2111. https://doi.org/10.1249/01. MSS.0000147585.65709.6F

[113] Whitham M, McKinney J. Effect of a carbohydrate mouthwash on running time-trial performance. J Sports Sci. 2007;25(12):1385-1392. doi:10.1080/02640410601113676

[114] Beelen M, Berghuis J, Bonaparte B, Ballak SB, Jeukendrup AE, van Loon LJ. Carbohydrate mouth rinsing in the fed state: Lack of enhancement of time-trial performance. Int J Sport Nutr Exerc Metab. 2009;19(4):400-409. https://doi.org/10.1123/ijsnem.19.4.400

[115] Cramer MN, Thompson MW, Périard JD. Thermal and cardiovascular strain mitigate the potential benefit of carbohydrate mouth rinse during self-paced exercise in the heat. Front Physiol. 2015;6:354. https://doi.org/10.3389/fphys.2015.00354

[116] Watson P, Nichols D, Cordery P. Mouth rinsing with a carbohydrate solution does not influence cycle time trial performance in the heat. Appl Physiol Nutr Metab. 2014;39(9):1064-1069. https:// doi.org/10.1139/apnm-2013-0413

[117] Pomportes L, Brisswalter J. Carbohydrate mouth rinse effects on physical and cognitive performance: Benefits and limitations in sports. SciSport. 2020 Sept.;35(4):200-206. https://doi.org/10.1139/ apnm-2013-0413

[118] Chandler MC, McGowan AL, Ferguson DP, Pontifex MB. Carbohydrate mouth rinse has no effects on behavioral or neuroelectric indices of cognition. Int J Psychophysiol. 2020 May;151:49-58. https:// doi.org/10.1016/j.ijpsycho.2020.02.012

[119] De Pauw K, Roelands B, Van Cutsem J, et al. Do glucose and caffeine nasal sprays influence exercise or cognitive performance? Int J Sports Physiol Perform. 2017;12(9):1186-1191. https:// doi.org/10.1123/ijspp.2016-0598

[120] Thomas DR, Cote TR, Lawhorne L, et al. Understanding clinical dehydration and its treatment. J Am Med Dir Assoc. 2008;9(5):292-301. https://doi.org/10.1016/j.jamda.2008.03.006

[121] Ganio MS, Armstrong LE, Casa DJ, et al. Mild dehydration impairs cognitive performance and mood of men. Br J Nutr. 2011;106(10):1535-1543. https://doi.org/10.1017/S0007114511002005

[122] Szinnai G, Schachinger H, Arnaud MJ, Linder L, Keller U. Effect of water deprivation on cognitivemotor performance in healthy men and women. Am J Physiol Regul Integr Comp Physiol. 2005;289(1):R275-R280. https://doi.org/10.1152/ajpregu.00501.2004

[123] Watson P, Black KE, Clark SC, Maughan RJ. Exercise in the heat: effect of fluid ingestion on blood-brain barrier permeability. Med Sci Sports Exerc. 2006;38(12):2118-2124. https://doi. org/10.1249/01.mss.0000235356.31932.0a

[124] Kempton MJ, Ettinger U, Foster R, et al. Dehydration affects brain structure and function in healthy adolescents. Hum Brain Mapp. 2011;32(1):71-79. https://doi.org/10.1002/hbm.20999

[125] Wittbrodt MT, Millard-Stafford M. Dehydration Impairs Cognitive Performance: A Meta-analysis. Med Sci Sports Exerc. 2018;50(11):2360-2368. https://doi.org/10.1249/MSS.0000000000001682

[126] Black MM. Micronutrient deficiencies and cognitive functioning. J Nutr. 2003;133(11 Suppl 2):3927S-3931S. https://doi.org/10.1093/jn/133.11.3927S

[127] Lachance L, Ramsey D. Food, mood, and brain health: implications for the modern clinician. Mo Med. 2015;112(2):111-115

[128] Perkins AJ, Hendrie HC, Callahan CM, et al. Association of antioxidants with memory in a multiethnic elderly sample using the Third National Health and Nutrition Examination Survey. Am J Epidemiol. 1999;150(1):37-44. https://doi.org/10.1093/oxfordjournals.aje.a009915

[129] Maddock J, Zhou A, Cavadino A, et al. Vitamin D and cognitive function: A Mendelian randomisation study. Sci Rep. 2017;7(1):13230. https://doi.org/10.1038/s41598-017-13189-3

[130] Avgerinos KI, Spyrou N, Bougioukas KI, Kapogiannis D. Effects of creatine supplementation on cognitive function of healthy individuals: A systematic review of randomized controlled trials. Exp Gerontol. 2018;108:166-173. https://doi.org/10.1016/j.exger.2018.04.013

[131] Hillman CH, Erickson KI, Kramer AF. Be smart, exercise your heart: exercise effects on brain and cognition. Nat Rev Neurosci. 2008;9(1):58-65. https://doi.org/10.1038/nrn2298

[132] Kujawski S, Kujawska A. How cognitive science can contribute to sport? How sport can contribute to neuroscience? Balt J Health Phys Act 2016;8(1):58-65. https://doi.org/10.29359/BJHPA.08.1.07 
[133] Cotterill ST. Team psychology in sports: Theory and application. Abingdon: Routledge; 2012. https:// doi.org/10.4324/9780203131428

[134] Tuomilehto H, Vuorinen VP, Penttilä E, et al. Sleep of professional athletes: Underexploited potential to improve health and performance. J Sports Sci. 2017;35(7):704-710. https://doi.org/10.108 0/02640414.2016.1184300

[135] Morin CM, Bootzin RR, Buysse DJ, Edinger JD, Espie CA, Lichstein KL. Psychological and behavioral treatment of insomnia:update of the recent evidence (1998-2004). Sleep. 2006;29(11):1398-1414. https://doi.org/10.1093/sleep/29.11.1398

[136] Thomas M, Sing H, Belenky G, et al. Neural basis of alertness and cognitive performance impairments during sleeping. Effects of $24 \mathrm{~h}$ of sleep deprivation on waking human regional brain activity. J Sleep Res. 2000;9(4):335-352. https://doi.org/10.1046/j.1365-2869.2000.00225.x

[137] von Rosenberg J. Cognitive Appraisal and Stress Performance: The Threat/Challenge Matrix and Its Implications on Performance. Air Med J. https://doi.org/10.1016/j.amj.2019.05.010

[138] Heijnen S, Hommel B, Kibele A, Colzato LS. Neuromodulation of aerobic exercise. A review. Front Psychol. 2016;6:1890. https://doi.org/10.3389/fpsyg.2015.01890

[139] Bermejo JL, Ribeiro B, Marco-Ahulló A, Villarrasa-Sapiña I, Garcia-Masso X. Effects of an incremental maximal endurance exercise stress-induced cortisol on cognitive performance. J Hum Sport Exerc. 2019;14(3):632-644. https://doi.org/10.14198/jhse.2019.143.13

[140] Bermúdez-Humarán LG, Salinas E, Ortiz GG, Ramirez-Jirano LJ, Morales JA, Bitzer-Quintero OK. From probiotics to psychobiotics: live beneficial bacteria which act on the brain-gut axis. Nutrients. 2019;11(4):890. https://doi.org/10.3390/nu11040890 